\title{
Evaluating Different Soil Tillage Surface Conditions On Their Rainwater Harvesting Potential in Botswana
}

\author{
W.J. Baipusi, ${ }^{1}$ B. Kayombo and C. Patrick \\ Department of Agricultural Engineering and Land Planning, Botswana College of Agriculture, Private Bag 0027 \\ Gaborone, Botswana
}

\begin{abstract}
Rain water harvesting $(\mathrm{RWH})$ is described as concentration, collection, storage and use of rain fall via runoff for various purposes such as domestic, livestock and agricultural use. RWH systems can be classified as macro, mini, micro and in-situ. A study was carried out during the 2013/14 cropping season to (1) characterize the soil tillage surface conditions on their runoff generation potential using micro-catchment RWH systems and (2) appraise the micro-catchment RWH systems resulting from different tillage systems on crop performance. In order to address stated objectives, two experiments were laid out. For specific objective one, a Completely Randomized Block Design comprising of three blocks of runoff/catchment plots measuring $25 \mathrm{~m}^{2}, 50 \mathrm{~m}^{2}$ and $100 \mathrm{~m}^{2}$ were laid out. Within the same plots/rainfall catchment, the following four soil surface conditions were imposed: Ploughed with moldboard surface (PS), Ploughed with mould board and un-weeded surface (UP), Ploughed with mould board and subsequently harrowed surface (HS) and naturally vegetated surface (NV). At the bottom of the catchment area, a runoff collection system was laid and runoff was measured after every storm event.

The second experiment was also a Completely Randomized Block Design with two factors i.e. catchment size (in-situ, $25 \mathrm{~m}^{2} 50 \mathrm{~m}^{2} \& 100 \mathrm{~m}^{2}$ ) and the four soil tillage surface conditions were repeated but this time a maize crop was planted at the bottom of the slope, such that runoff was collected at the cropped area. Plant performance (growth rate) was assessed fortnightly, by measuring 10 plants' height of the mid-leaf or growing point, from each plot.

The results showed that a $5 \times 5 \mathrm{~m}$ mould board ploughed and un-weeded surface yielded significantly more runoff than other catchment areas and surface condition combinations. With respect to crop performance, a $5 \times 5$ $\mathrm{m}$ catchment whose runoff was directed to a mould board ploughed cropped area had a significantly higher growth rate of maize than run-off from other catchment areas and surface condition combinations.
\end{abstract}

Key Words: Tillage Systems, Micro-Catchment Rainwater Harvesting, Runoff, Catchment Size, Soil Surface Condition, Growth Rate.

\section{INTRODUCTION}

The ever increasing world population is putting pressure on available agricultural land. In order to produce more food, new methods should be found to increase land productivity or to bring into production land which is marginal. There are almost 600 million hectares of potentially suitable arable land in semi-arid environments, where dry-land farming is still practiced. Arable farming in these areas is hampered by low and erratic rainfall, endemic droughts and uneven distribution of land and water resources (FAO 1991). Botswana has a land area of $582,000 \mathrm{~km}^{2}$, but of this, $80 \%$ is covered by the Kalahari sands in the west and central regions. It is reported that only 5\% of total land area is suitable for arable agriculture and of this area, less than $6,000 \mathrm{~km}^{2}$ is under cultivation (African Development Bank, 2008). Botswana's climate is characterized as semi-arid in the northeast with mean annual rainfall of $650 \mathrm{~mm}$; and arid in the southwest with less than $250 \mathrm{~mm}$ mean annual rainfall.

All the same, agriculture in Botswana plays a very important role in the economy as more than $80 \%$ of the population is involved in agriculture. The government considers arable and livestock farming as key areas for employment creation and income generation for the majority of rural families (Botswana Government, 2000). Climate is a key factor in determining the level to which both crop production and livestock rearing succeed in any particular year. Rainfall and temperatures are the main elements which influence whether a season is good or dry leading to drought. Rainfall is seasonal, unreliable and varies from year to year (Botswana Government, 2000).It is

${ }^{1}$ Corresponding Author: bkayombo@gmail.com 
therefore very crucial that every effort is made to conserve and efficiently utilize the scarce rain water(Moroke et al. 2009).For arable crop production, this requires improved soil management techniques that maximize the holding of rain-water into the soil, coupled with cultural and agronomic practices which ensure the most optimum use of the available soil-water by plants .An optimization of the rainfall management can contribute to improving the small scale farmers' livelihoods by increasing arable cereal yields by $17 \%$ (Kayombo et al., 2004) and (Ibraimo\&Munguambe, 2007).Rain Water Harvesting (RWH) is defined as a process of collecting, concentrating and storing various forms of runoff for various purposes (Myers, 1975). The collected runoff can be used for several purposes such as to improve soil-moisture for plants, to supply water for livestock and domestic needs and to recharge the groundwater (Frasier, 1994).

\subsection{Depending on the Storage Capacity Available in the Root Zone, the Management of Rainwater for Plant Growth Can be Carried out in Three Successive Steps:}

Capture of rainwater to enhance its infiltration into the soil profile;

$>$ Prevention or reduction of water losses from the root zone; and

Implementation of cultural practices to ensure that the crop makes the most effective use of the scarce water.

The techniques for achieving these have been developed and promoted extensively under the subject of Soil and Water Conservation (Tiffen et al., 1994; Tulu, 2002; Hellin, 2006).

In order to improve the productivity of rainwater in semi-arid areas, it is often necessary to concentrate it into a small area of use through some form of tillage.

The broad aim of this research was to investigate to what extent common tillage systems and the resulting soil surface conditions practiced in Botswana can harvest rain water and also if those quantities harvested can support a maize crop. Common tillage systems and soil surface conditions prevalent in Botswana include:

$>$ Mould board ploughed, row planted and weeded soil surface

$>$ Mould board ploughed, disc harrowed, row planted and weeded soil surface

$>$ Mould board ploughed and un-weeded soil surface

The above soil surfaces, together with an un-ploughed soil surface with vegetation (control) were used as treatments in the study.

\subsection{Objectives}

The main objective of the study was to evaluate micro-catchment RWH using catchment size and soil surface tillage condition as variables for improved crop production.

\subsection{The Specific Objectives of The Study Were}

To determine the relationship between catchment size and runoff generation potential on differently tilled soil surface conditions;

To appraise the resultant micro-catchment RWH systems from common tillage systems on crop performance.

\section{Materials AND Methods}

A field study was conducted during the 2013/14 cropping season at the Botswana College of Agriculture Farm ( $24^{0}$ $33^{\prime}$ S: $25^{\circ} 54^{\prime}$ E; $994 \mathrm{~m}$ above sea level), about $15 \mathrm{~km}$ North-East of Gaborone. The climate is semi-arid with an average annual rainfall of $538 \mathrm{~mm}$. Most rainfall occurs in summer, which generally starts in late October and continues through March/April. Prolonged dry spells during the rainy season are common and rainfall tends to be localized. The soils are shallow, ferruginous tropical soils, mainly consisting of medium to coarse grain sands and loams with a low water holding capacity and subject to crusting after heavy rains. The soils in the area are classified as hepliclixisols, according to the FAO Soils Classification system (FAO, 1993).Mean maximum and minimum temperatures of the area vary between $33.1-34.7^{\circ} \mathrm{C}$ and $19.2-19.5^{\circ} \mathrm{C}$ respectively (Ramolemana, 1999). The fertility status is medium and the farm was initially used for vegetable production. The study consisted of two experiments addressing each of the two specific objectives. For both experiments, a Completely Randomized Block Design comprising of three blocks was set up and blocking was against variability of soil and slope distance. Three runoff/catchment plots measuring $5 \times 5 \mathrm{~m}, 5 \times 10 \mathrm{~m}$ and $5 \times 20 \mathrm{~m}$ were laid out, within the same plots/catchment area, 
the following soil surface conditions were imposed: Ploughed with mould board surface (PS), Ploughed with moldboard and un-weeded surface (UP), Ploughed with mould board and subsequently harrowed surface (HS) and naturally undisturbed vegetated surface (NV). To obtain different soil surface conditions as outlined previously, the mould board plough surface was effected first and thereafter a disc harrow was either used or not depending on the treatment. For the Un-weeded soil surface, mould board plugging was followed by disc harrowing where-after theplot was not weeded for the entire period of experimentation, in order to distinguish this treatment from the Natural Vegetated soil surface. Ridges were then made with spades and rakes to ensure that the rainwater would be directed into the cultivated basins down slope .As part of characterization of the different soil surface conditions, soil parameters i.e. soil bulk density, field hydraulic conductivity, infiltration rate and soil moisture content were measured, whilst soil porosity was calculated. The soil cores for bulk density determination were collected prior to experiment commencement and during the rainy season, down to $10 \mathrm{~cm}$ depth, for all treatments. The soil cores were placed in an oven at $105^{\circ} \mathrm{C}$ and dried until a constant weight was achieved according to Blake and Hartge (1986). As for total porosity (i.e. the volume of voids in a core sample expressed as percentage), was calculated from the relationship between bulk density and particle density (i.e. the density of the solid material viz. $2.65 \mathrm{gcm}-3$ for most mineral soils), according to Danielson and Southerland (1986) and calculated as shown in equation 1 below:

$\mathrm{f}=1-\frac{\rho \mathrm{d}}{\rho \mathrm{p}} \times 100$

Where:

$\mathrm{f}=$ total porosity

$\rho \mathrm{d}=$ dry bulk density

$\rho p=$ particle density

Soil moisture measurements for all treatments were measured before experiment commencement, during the rainy season and after the rainy season by the gravimetric soil water measurement method according to Gardner (1986). Samples were obtained randomly for all treatments. The rate of water infiltration was measured before experimental commencement by the double ring in filter meter with an inner ring diameter of $25.5 \mathrm{~cm}$ and the saturated hydraulic conductivity of the soil was determined also before experimental commencement by the variable head permeameter according to Klute (1986) by sampling to the depth of $30 \mathrm{~cm}$.In order to obtain the actual ratio of the overflow that drained into the collector drum a calibration of the runoff collection system was done and a depth to volume calibration curve (Figure 1) was produced for all the drums. Subsequently, the same ratio was used to calculate the total runoff from the catchment area in question.

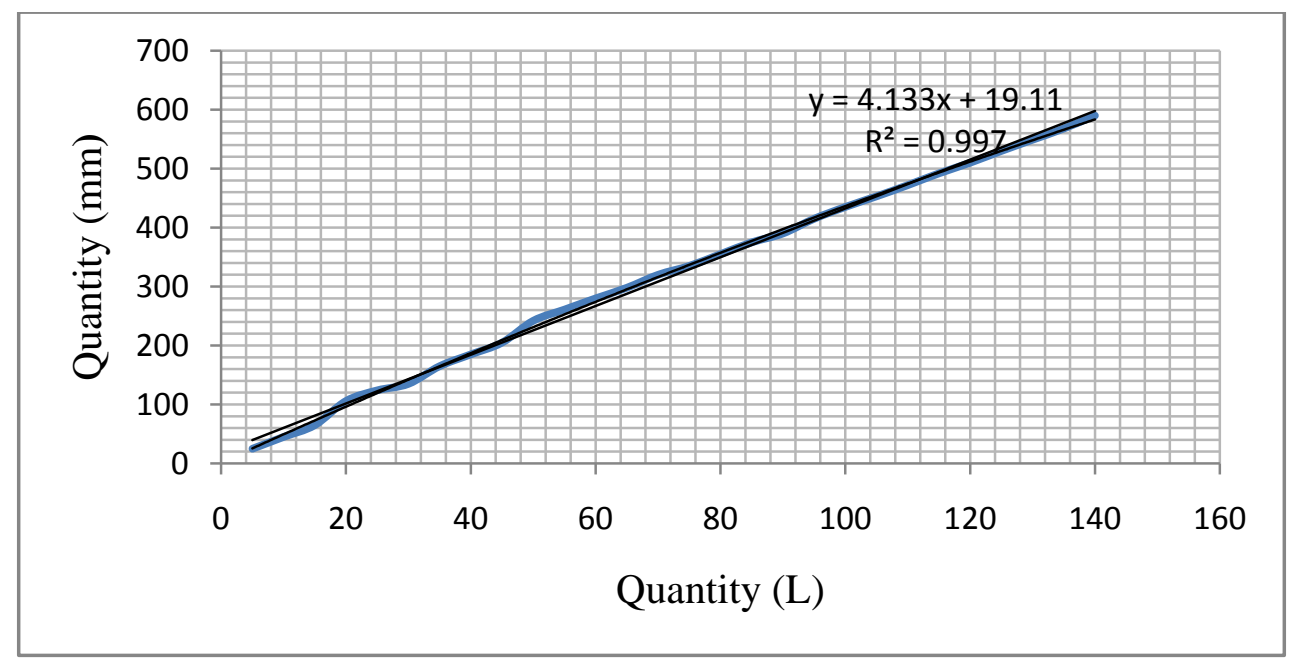

Fig1. Calibration Curve for 210 liter runoff collection drums

A conventional method of measuring runoff from the various sized plots involved employing a number of collecting tanks (drums) with a divisor between any two of them (FAO, 1993). This consisted of the divider drum with 15 outlet pipes of diameter $2 \mathrm{~cm}$. The central pipe was connected to the collector drum by a hose pipe. The overflow 
pipes of the divider drum were adjusted such that the overflow volume draining into the collector drum was $1 / 15$ of the total overflow. The runoff collection system is shown in Plate 1.

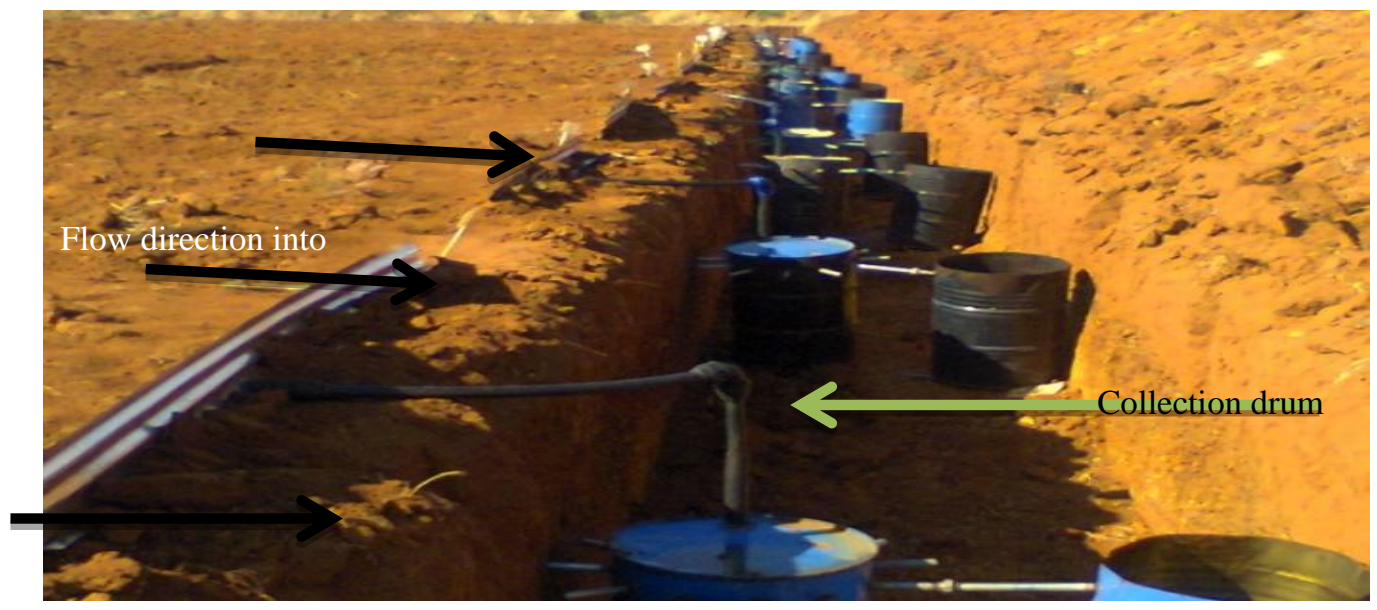

Plate 1: Runoff collection system

After each rainfall event the depth of runoff collected into the 210 liter drums (of the runoff collection system) was measured by a meter rule $(\mathrm{mm})$. Then the conversions, from millimeter $(\mathrm{mm})$ to liters $(\mathrm{L})$, were obtained from the calibration curve.An analysis of variance (ANOVA) was then conducted using Statistical Software (SAS Inst., 2008). Mean separations were achieved by using Duncan's least significant difference (LSD). A probability level of less than 0.05 was designated as significant.

For specific objective two which was to appraise the micro-catchment RWH system on crop performance, a Completely Randomized Block Design, with two factors, i.e. soil surface condition and catchment area was laid out. Blocking was against varying slope length and soil type so that the variation did not cause any bias on the results. Just as it was done for the first experiment, the field experiment consisted of two factors, soil surface condition and catchment size. The same soil surface conditions and Catchment sizes imposed for the first objective were repeated. Maize (Zea mays) was used as a test crop and planted to $0.9 \mathrm{~m}$ inter-row spacing and $0.6 \mathrm{~m}$ intra row spacing using hands. Due to wildlife damage, only growth rate was used as a performance indicator. The plant height was measured fortnightly from ten random plants and the reading was taken from growth point of each plant measured and the data was analyzed as for the first objective experiment.

\section{RESULTS AND DISCUSSION}

\subsection{Characterization of Soil Surface Conditions}

Physical characteristics for the experimental field for objective 1 were almost similar, with range of infiltration varying from $12 \mathrm{mmh}-1$ to $14 \mathrm{mmh}-1$, while hydraulic conductivity varied from $1.28 \times 10-1 \mathrm{cmsec}-1$ to $1.33 \times 10$ $1 \mathrm{cmsec}-1$ amongst the soil surface conditions. These results are shown in Table 1.

Table1. Summary of the physical characteristics of the experimental field for objective 1

\begin{tabular}{|l|l|l|l|l|}
\hline Soilsurface & Bulk density $\left(\mathrm{gcm}^{3}\right)$ & Porosity & Infiltration rate $\left(\mathrm{mmh}^{1}\right)$ & Hydraulic conductivity $\left(\mathrm{cmsec}^{1}\right)$ \\
\hline HS & $1.53 \mathrm{~b}$ & 0.41 & 12.5 & $1.31 \times 10^{-1}$ \\
\hline NV & $1.41 \mathrm{~b}$ & 0.46 & 12 & $1.30 \times 10^{-1}$ \\
\hline UP & $1.67 \mathrm{a}$ & 0.37 & 12 & $1.28 \times 10^{-1}$ \\
\hline PS & $1.48 \mathrm{~b}$ & 0.44 & 13 & $1.33 \times 10^{-1}$ \\
\hline
\end{tabular}

\subsection{Soil Surface Conditions}

When making a comparison between soil surface conditions, it was found that runoff collected from Un-Weeded Plot (UP), over the season, was significantly higher (Table 2) than runoff from Harrowed surface (HS), Natural vegetation (NV) and Ploughed with mould board (PS) surface by 59\%, 45\% and 34\%, respectively.

Table2. Effects of soil surface condition on runoff 
American Research Journal of Agriculture, Volume 1, Issue 2, April 2015

ISSN 2378-9018

\begin{tabular}{|l|l|l|}
\hline Soil surface & Runoff $(l)$ & Percentage difference $(\%)$ \\
\hline Un-Weeded Plot & $26.7 \mathrm{a}$ & \\
\hline Natural Vegetation & $17.75 \mathrm{~b}$ & 34 \\
\hline Ploughed with mould board & $14.72 \mathrm{~b}$ & 45 \\
\hline Harrowed & $10.94 \mathrm{~b}$ & 59 \\
\hline
\end{tabular}

Means with same letters are not significantly different at $P<0.05$, using Duncan Least Square

More runoff collected in Un-Weeded plot corresponds with soil physical properties (bulk density, porosity and infiltration rate) in sense that soil bulk density of Un-Weeded plot was significantly higher $(1.69 \mathrm{gcm}-3)$ than in Harrowed $(1.54 \mathrm{gcm}-3)$, Ploughed with mould board surface $(1.48 \mathrm{gcm}-3)$ and Natural vegetation $(1.41 \mathrm{gcm}-3)$ surface. This explains why Un-Weeded plot recorded highest runoff over the season. An increase in soil bulk density (low porosity and slow water permeability) significantly increases runoff. This view is supported by El Atta and Aref (2010), who reported that as soil bulk density increased, soil porosity decreased which limited depth of water flowing through the soil thereby increasing the depth of water flowing on the surface as run off. Total runoff recorded on Un-Weeded Plot also correlated with porosity and infiltration rate (table 1), as more runoff, less infiltration rate were recorded as compared to other soil surface. The results are similar to El Atta and Aref (2010)'s reports, the latter noted that the more the infiltration rate, the less the runoff and vice versa.

\subsection{Catchment Area}

A comparison between the catchment sizes (Table 3 ) revealed that a $5 \mathrm{~m} \times 5 \mathrm{~m}$ catchment was significantly different from $10 \mathrm{~m} \times 5 \mathrm{~m}$ and $20 \mathrm{~m} \times 5 \mathrm{~m}$ catchments, at $\mathrm{P}<0.05$. A $5 \mathrm{~m} \times 5 \mathrm{~m}$ catchment recorded $67 \%$ more runoff than a $10 \mathrm{x}$ $5 \mathrm{~m}$ and $20 \mathrm{~m} \times 5 \mathrm{~m}$.

Table3. Effects of catchment size on runoff means

\begin{tabular}{|l|l|}
\hline Catchment size & Mean runoff $(l)$ \\
\hline $5 \mathrm{~m} \times 5 \mathrm{~m}$ & $100.6 \mathrm{a}$ \\
$10 \mathrm{~m} \times 5 \mathrm{~m}$ & $33.5 \mathrm{~b}$ \\
$20 \mathrm{~m} \times 5 \mathrm{~m}$ & $32.7 \mathrm{~b}$ \\
\hline
\end{tabular}

Means with same letters are not significantly different at $P<0.05$, using Duncan Least Square

From these results, it is possible to generate significant runoff from a small piece of land (vis. $25 \mathrm{~m} 2$ ) for crop growth if soil properties are similar.

\subsection{Characterization of Soil Surface Conditions}

The physical characteristics of the experimental field are shown in Table 1. Moisture measured at the end of the season varied from the moisture measured at the beginning of the experiment. The results revealed that the soil surface ploughed with moldboard was able to retain moisture than other soil surface conditions (Table4).

Table4. Amount of moisture recorded at the beginning and end of the experiment

\begin{tabular}{|l|l|l|}
\hline \multirow{2}{*}{ Soil surface } & Moisture (\%) \\
\cline { 2 - 3 } & Before & End \\
\hline Ploughed with moldboard & $1.3 \mathrm{a}$ & $1.95 \mathrm{a}$ \\
\hline Harrowed & $0.9 \mathrm{a}$ & $1.13 \mathrm{~b}$ \\
\hline Un-Weeded Plot & 1.2 & $0.53 \mathrm{c}$ \\
\hline
\end{tabular}

Means with same letters are not significantly different at $P<0.05$, using Duncan Least Square

\subsection{Effect of Soil Surface Condition on Growth Rate}

There was significant difference of growth rate between Ploughed with mould board surface (PS), Harrowed surface (HS) and Un-Weeded plot (UP). Ploughed with mould board surface had an increase of $22 \%$ and $28 \%$ in growth rate over Harrowed (HS) and Un-Weeded plot (UP), respectively (Table 5). Growth rate was correlated to amount of moisture measured from the said soil surface conditions and catchment sizes. Soil moisture in Ploughed with 
mouldboard soil surface $(1.95 \% \mathrm{w} / \mathrm{w})$ was significantly higher than in Un-Weeded plot $(0.53 \% \mathrm{w} / \mathrm{w})$. This accounts for difference in growth rate between the Ploughed with mould board (PS) surface and Un-Weeded plot.

Table5. Effect of soil surface condition on growth rate

\begin{tabular}{|l|l|l|}
\hline Soil surface & Growth rate $(\mathrm{cm} /$ week $)$ & $\%$ difference \\
\hline Ploughed with mouldboard & $7.9 \mathrm{a}$ & \\
\hline Harrowed & $6.2 \mathrm{~b}$ & 22 \\
\hline Un-weeded plot & $5.7 \mathrm{~b}$ & 28 \\
\hline
\end{tabular}

Means with same letter are not significantly different at $P<0.05$ using Duncan Least Square Means

\subsection{Effect of Catchment Area on Growth Rate}

Runoff collected from a 5m x 5m catchment had $43 \%$ increase in growth rate over a control (where there was no runoff directed to cropped area) while a $10 \mathrm{~m} \times 5 \mathrm{~m}$ had an increase in growth rate of $34 \%$ (Table 6). These results agree with those of Kayombo et al. (2004) who reported that an increase of Catchment to Basin Area Ratio (CBAR) resulted in higher yields in a semiarid area of Tanzania. Similarly, moisture in a $5 \mathrm{~m}$ x $5 \mathrm{~m}$ was significantly higher $(1.51 \% \mathrm{w} / \mathrm{w})$ than in a control plot $(0.96 \% \mathrm{w} / \mathrm{w})$, which accounted for $43 \%$ of growth rate of maize in a $5 \mathrm{~m} \times 5 \mathrm{~m}$ catchment (Table 6).

Table6. Effects of catchment size on growth rate

\begin{tabular}{|l|l|l|l|}
\hline Catchment size $(\mathbf{m})$ & Growth Rate $(\mathbf{c m} /$ week) & \% increase due to RWH & Moisture \% \\
\hline $5 \mathrm{~m} \times 5 \mathrm{~m}$ & $9 \mathrm{a}$ & & $1.51 \mathrm{a}$ \\
\hline Control (no runoff) & $5.1 \mathrm{c}$ & 43 & $0.96 \mathrm{~b}$ \\
\hline $5 \mathrm{~m} \times 10 \mathrm{~m}$ & $5.9 \mathrm{~b}$ & 34 & $1.07 \mathrm{~b}$ \\
\hline $5 \mathrm{~m} \times 20 \mathrm{~m}$ & $5 \mathrm{c}$ & 44 & $1.2 \mathrm{~b}$ \\
\hline
\end{tabular}

Means with same letter are not significantly different at $P<0.05$ using Duncan Least Square Means

\section{CONCLUSIONS}

A 5 x $5 \mathrm{~m}$ un-weeded surface yielded significantly more runoff than other catchment area - surface condition combinations.

$>$ A 5 x 5 m catchment whose runoff was directed to a mould board ploughed cropped area had a significantly higher growth rate of maize than other catchment area - surface condition combinations.

\section{RECOMMENDATIONS}

Farmers should utilize uncultivated/fallow land (as small as $5 \times 5 \mathrm{~m}$ area) to generate runoff from rainfall for crop growth.

\section{REFERENCES}

[1] African Development Bank, 2008. Botswana Pandamatenga Agricultural Infrastructure DevelopmentProject Appraisal Report, OSAN.1, June 2008.

[2] Blake, G.R. and Hartge, K.H., 1986. Bulk density. In: Methods of Soil Analysis, Part 1, pp. 363-375. Klute, A. (Ed), American Society of Agronomy and Soil Science Society of America, Madson, Wisconsin, USA.

[3] Botswana Government, 2000.Botswana National Atlas.Botswana Government, Gabonone.

[4] Danielson, R.E. and Sutherland, P.L., 1986. Porosity. In: Methods of Soil Analysis, Part 1, pp. 443-460.Klute, A. (Ed), American Society of Agronomy and Soil Science Society of America, Madson, Wisconsin, USA.

[5] El Atta, H.A and Aaref, I., 2010. Effects of terracing on rainwater harvesting and growth of JuniperusproceraHochst.exExndlicher. International Journal of Environment Science and Technology, 7(1):59-66.

[6] Food and Agriculture Organisation (FAO), 1991. Water harvesting: The significance of soil porosity. A Manual for the Design and Construction of Water Harvesting sechmes for plant production. Rome, Italy.

[7] Food and Agriculture Organisation (FAO), 1993.Field measurement of soil erosion and runoff. FAO Soils bulletin 68. Rome, Italy.

[8] Food and Agriculture Organisation (FAO), 2013. Irrigation Water Management: Irrigation water needs. Rome, Italy. 
[9] Frasier, G.W., 1994.Water harvesting/runoff-farming systems for agricultural production. In: Water harvesting for improved agricultural production. Proceedings of the FAO Expert Consultation, Cairo, Egypt, November 1993, FAO, Rome, pp. 57-71.

[10] Gardner, H.W., 1986. Soil moisture. In: Methods of Soil Analysis, Part 1, pp. 493-541. Klute, A. (Ed), American Society of Agronomy and Soil Science Society of America, Madson, Wisconsin, USA.

[11] Hellin, J., 2006. Better Land Husbandry.Science Publishers, Enfield, New Hampshire.

[12] Ibraimo, N. and Munguambe, P., 2007. Rainwater Harvesting Technologies for small Scale Agriculture in Arid and SemiArid Areas, Integrated Water Resources Management for Improved Rural Livehoods. Water net.

[13] Kayombo, B., Hatibu, N. and Mahoo, H.F., 2004. Effect of Micro-Catchment Rainwater Harvesting on yield of maize in a semi-arid area.13th International Soil Conservation Organisation Conference. Brisbane.

[14] Klute, A., 1986. Methods of Soil Analysis, Part 1. American Society of Agronomy and Soil Science Society of America, Madson, Wisconsin,USA.

[15] Moroke, T.S., Dikinya, O. and Patrick, C. 2009. "Comparative assessment of water infiltration of soils under different tillage systems in eastern Botswana".Physics and Chemistry of the Earth. Vol. 34, pp 316-323.

[16] Myers, L.E., 1975. Water harvesting, 2000 B.C to 1974 A.D In: Fraiser, G.W. (ed). Proceedings of Water Harvesting Symposium, Phoenix, Arizona, March 1974, pp.1-7.

[17] Ramolemana, G.M., 1999. The phosphorus and nitrogen of Bambara groundnut (Vignasubterrana (L.) verdc.) in Botswana soils: An exploratory study. ISBN 90-5808-020X.

[18] SAS, 2008. SAS release 9.2. SAS Institute Inc. Cary, North Carolina, USA

[19] Tiffen, M., Mortimore, M. and Gichuki, F., 1994. More People Less Erosion. John Wiley \& Sons, West Sussex.

[20] Tulu, T., 2002.Soil and Water Conservation for Sustainable Agriculture.Mega Publishing Enterprise, Addis Ababa, Ethiopia. 